\title{
Fire modeling in a nonventilated corridor
}

\author{
Marius Dorin Lulea ${ }^{1, *}$, Vlad Iordache $^{2}$, and Ilinca Năstase ${ }^{2}$ \\ ${ }^{1}$ PHD at Technical University of Civil Engineering of Bucharest, Romania \\ ${ }^{2}$ Research Center CAMBI, Technical University of Civil Engineering of Bucharest, Romania
}

\begin{abstract}
The main objective of this study was to determine the effect of fire in a nonventilated corridor. A real-scale model of a corridor has been modeled in Fire Dynamics Simulator(F.D.S.) in order to determine the evolution of indoor temperatures, the visibility and the oxygen quantities during a fire. The start time of a sprinkler has also been determined. The use of sprinklers in buildings has become a necessity and a requirement imposed by technical norms. The provision of this type of installation has become a common feature in buildings with a high fire risk, with two main effects: fire extinction and protection of structural and partition elements from high temperatures[15]. The ultimate goal is to ensure optimal conditions for saving the building users, intervention teams and maintaining the stability of the building. Low temperatures and good visibility on the escape routes during a fire are the basic conditions to ensure the optimal evacuation of users.
\end{abstract}

\section{Introduction}

The main purpose of fire safety processes is to save the users of the buildings. Beside this main purpose, the following aspects have a particular importance: ensuring fire-fighting interventions conditions, preventing the collapse of buildings, limiting the spread of fire inside the buildings or to other buildings and, ultimately, limiting financial losses[1].

Under these conditions it is imperative to protect the escape routes[2] by maintaining low temperatures, good visibility and low concentration of toxic gases resulting from the fire. For a period of time hallways, stairwells and corridors must be protected area in case of fire, required to ensure the evacuation safely of users. The norms[2] requires that the time to evacuate users to be as short as possible. For example, for one-way evacuation, it should be limited to 20 seconds- $6 \mathrm{~m}$ (buildings made from combustible materials) and up to 70 seconds $-21 \mathrm{~m}$ (non-combustible materials with fire performance).

Fire protection of a building can be achieved by the application of passive protection measures or active protection measures[3]. Passive fire protection of buildings refers, in general, to structural and architectural compliance. This category includes fire requirements for: columns, beams, floors, interior and exterior walls, roof and covering[2]. Active fire protection refers to the use of automated systems that do not require human intervention and which also affect the fire, the source of the fire and its products. This category includes fire extinguishers with sprinklers[4], mechanical ventilation systems for fire protection, inert gas installations, fog extinguishing systems, powder extinguishing systems and others.

The protection of the escape routes can be done by using fire-resistant partition elements(walls, floors, doors), smoke and hot gas automatic extraction(natural or mechanical evacuation of smoke), or/and sprinkler equipment.

Sprinklers produce beneficial effects due to the following mechanisms[5]: reduce air temperatures and material temperatures, decrease heat load of materials(the combustion) by increasing humidity, makes a non-combustible water film on the surface of the materials, decreases the oxygen concentration by increasing the amount of water vapor resulting from contact of droplets with hot surfaces and others.

There are many design cases where the experts are asking themselves: what is the maximum acceptable length of an unventilated or unprotected corridor without significantly disrupting users' evacuation? How long time is available for the users to evacuate in safety condition?

The present study is oriented towards to determine the time during which an unventilated and unprotected corridor, affected by fire, becomes unsafe for evacuation. The study also aims to determine the time at which the first sprinkler will be initiated in the corridor. 

fires:

There are three methods currently used for modeling

- simplified mathematical models[6];

- zonal models[7];

- field models[8].

The most common and simplest method at this time is the one given by the Eurocode[6] and which provides a function time- temperature of indoor air(fig. 1). The method is simple to use but presents the disadvantage that it leads to an overvaluation of the consequences of the fire and can leads to unreasonable consumptions of materials. The model proposes equal temperature in all building volumes, and the representation is not realistic[8].

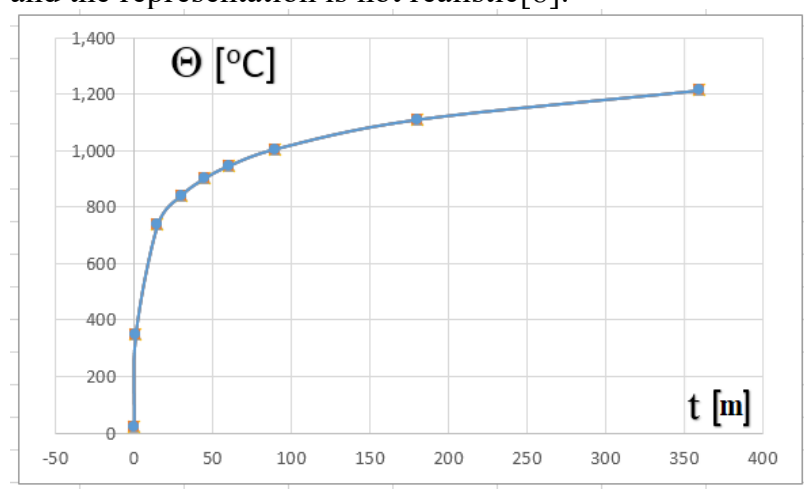

Fig. 1. The Time-Temperature variation curve SR EN1991-1-2

Global direction is to shift from the simplified models to field models that provide a more realistic representation of the fire[9]. This is happening with the development of computing technologies. In the case of important constructions, realistic modeling of the fire is required because it leads to an efficient consumption of materials and helps the designer to establish correct and justified design solutions. Simplified modeling, for example on the basis of the standard Eurocode temperature curve, is a covering and often leads to ineffective solutions.

In order to reach our proposed goals, we made a modeling in F.D.S. of a fire in a nonventilated corridor. In the present study it was analyzed the time evolution of the next parameters: indoor air temperature, visibility and oxygen concentration at different characteristic points.

\section{Modeling Fire Dynamics Simulator(F.D.S.) and Case Study}

This research involves modeling of a fire in a nonventilated corridor using F.D.S. This is a computational fluid dynamics (CFD) model of firedriven fluid flow. The software solves numerically a form of the Navier-Stokes equations appropriate for lowspeed, thermally-driven flow $(\mathrm{Ma}<0,30)$, with an emphasis on smoke and heat transport from fires.

The Fire Dynamics Simulator and Smokeview are the products of an international collaborative effort led by the National Institute of Standards and Technology
(NIST) and VTT Technical Research Centre of Finland. The F.D.S. currently takes the form of a programming tools and it provides to users unlimited and explicit access to the algorithm or other data.

F.D.S. includes certain restrictions and simplifications for modeling fluid motion and make algorithms to respond effectively purpose: to study the effect of fire.

It is important, in the design of a building, to model the fire by controlling the parameters that lead to the role of fire safety systems:

- the distribution of temperature in time and space;

- the distribution of smoke in time and space;

- the distribution of combustion gases in time and space.

To determine the equations solutions, F.D.S. uses the following models:

Method to solve the Navier-Stokes equations- use finite volume method to solve the numerical problem;

Turbulent flow- Large Eddy Simulation(fig. 2), neglecting small turbulence which require important calculation resources, but having a low effect on the final result;

Geometry- F.D.S. uses a 3D model with rectiliniar grid with the possibility of multiple mesh(fig. 3);

Fire source- specify the heat release rate per unit area(HRRUA);

Burning- the burning process releases heat, gases and smoke; the combustion model assumes that each cell initiates, maintains or stops burning when a certain temperature is reached and there is a certain ratio of gas to oxygen (more than 14\%). By default, F.D.S. uses the mixed fraction model with two parameters- the first parameter represents the unburn fuel fraction and the second parameter fraction of the fuel that has been burned. We can also choose a two-phase model (phase 1: obtaining $\mathrm{CO}$ and phase $2 \mathrm{CO} 2$ production) with three parameters, involving a burned fuel fraction, the burned fuel fraction in phase 1 and the burned fuel fraction in phase 2 . To make the simulations tractable, the author limits the number of fuels to one, and the number of reactions to just one or two.

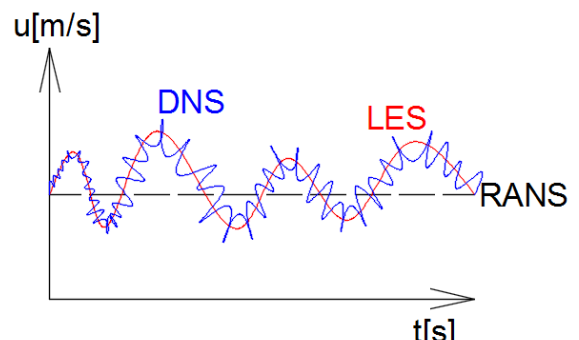

Fig. 2. Methods used in C.F.D. numerical type simulation

The F.D.S. modeling consist of divide the domain into thousands of cells. For each cell is known at a certain time various parameters such as: temperatures, velocity, visibility, gas concentrations, quantity of material (unconsumed combustible, burned fuel or noncombustible material)[9]. Each cell changes its parameters over time according to the characteristics of 
the other cells from space and the external forces acting on the given domain.

The current study involved the burning inside a closed corridor with the dimensions of $7,80 \mathrm{~m} \mathrm{x} 1,80 \mathrm{~m} \times$ $2,80 \mathrm{~m}$ (fig. 4). The corridor has no natural or mechanical ventilation.

The tridimensional rectilinear mesh is composed of regular cells with the following dimensions: $0,10 \mathrm{~m} \mathrm{x}$ $0,10 \mathrm{~m} \times 0,10 \mathrm{~m}$. This means that the domain analyzed consists of 176000 cells, each coming with its own physical and chemical equations interrelated(fig. 3).

The corridor is included in an analysis space with the following dimensions: $11,00 \mathrm{~m} \times 4,00 \mathrm{~m} \times 4,00 \mathrm{~m}$ (fig. 4).

Two slots(F1, F2) were provided at the lower part of the corridor: $1,00 \mathrm{~m} \times 0,10 \mathrm{~m}$ - simulates air infiltration in adjoining rooms.

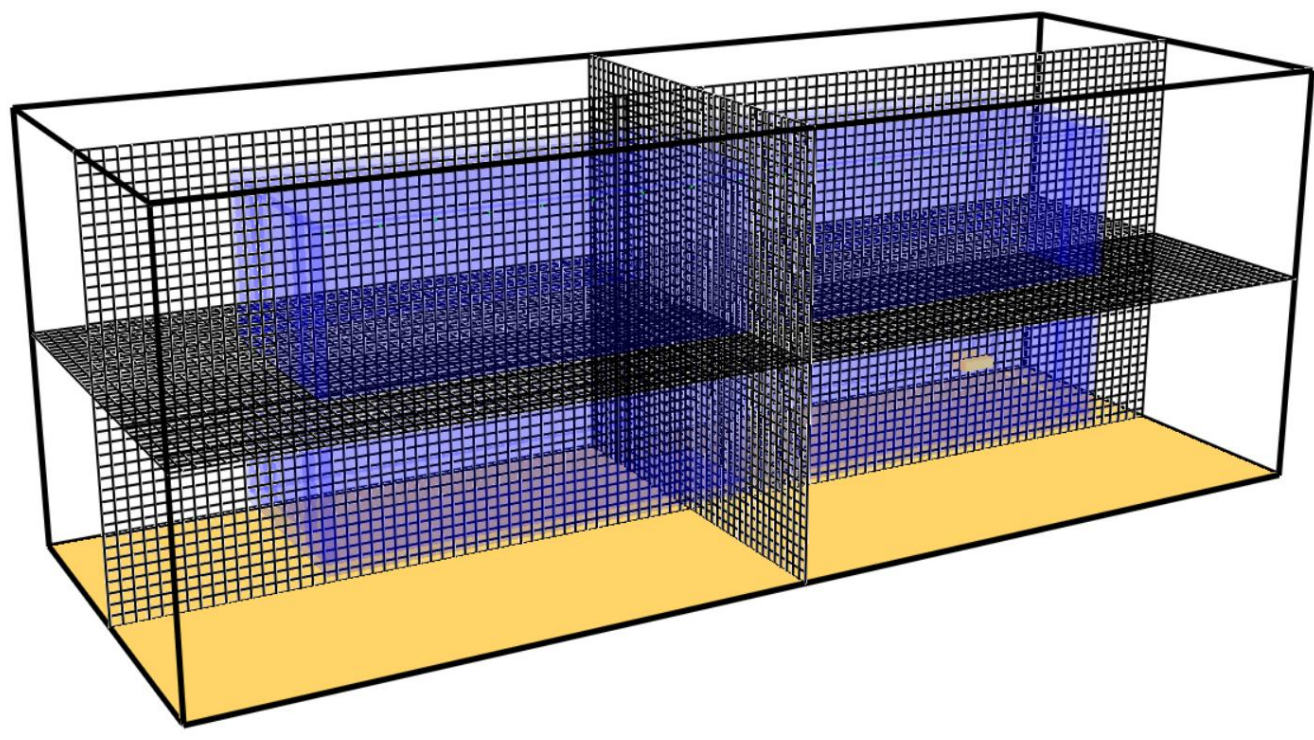

Fig. 3. Domain mesh- $10 \mathrm{~cm} \times 10 \mathrm{~cm}$

The fire source was provided at one end of the corridor. We have specified the fire by a given Heat Release Rate per Unit Area(HRRPUA): $450 \mathrm{~kW} / \mathrm{m}^{2}$. The burner has the dimensions of $0,30 \mathrm{~m} \times 0,40 \mathrm{~m}$ (fig.5).

$$
H R R=H R R P U A x S_{\text {burner }} \quad[k W]
$$

$$
H R R=54 k W[k W]
$$

The fuel used is "wood", characterized by a Lower Heating Value(LHV) of 17,700 [MJ/kg]. The quantity of soot released in the air during the fire is considered equal to $0,02 \mathrm{~kg}$ soot $/ \mathrm{kg}$ combustible.

For comparation, the maximum HRR reach about 4,0MW for a single car fire[12].

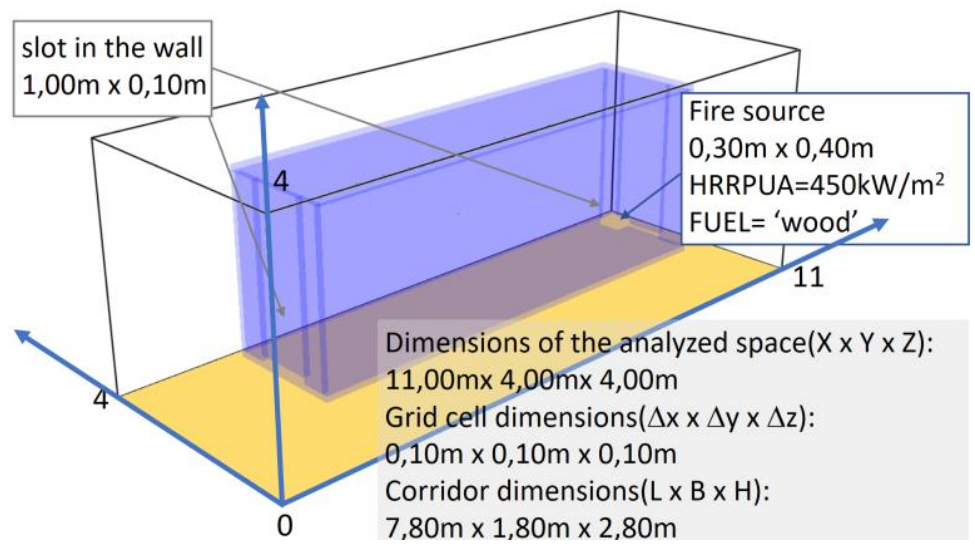

Fig. 4. Fire space characteristics 


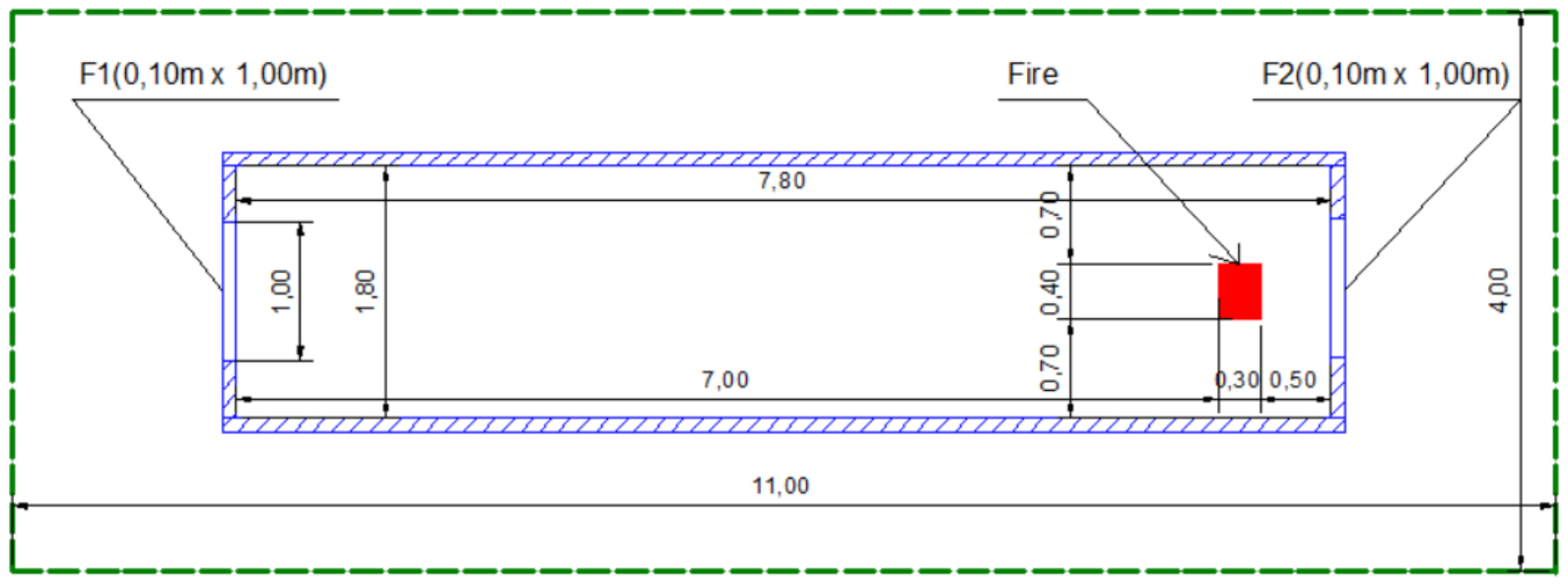

Fig. 5. Model plan

In the corridor there were mounted 15 temperature sensors $(\mathrm{S} 1-\mathrm{S} 15)$ at $30 \mathrm{~cm}$ from the $\operatorname{ceiling}(\mathrm{z}=2,50 \mathrm{~m})$. The distance between sensors is $50 \mathrm{~cm}$ (fig. 6). The sensors have been installed at the same level as usually sprinklers are.
The parameters that characterize the fire were followed for a period of 360 seconds.

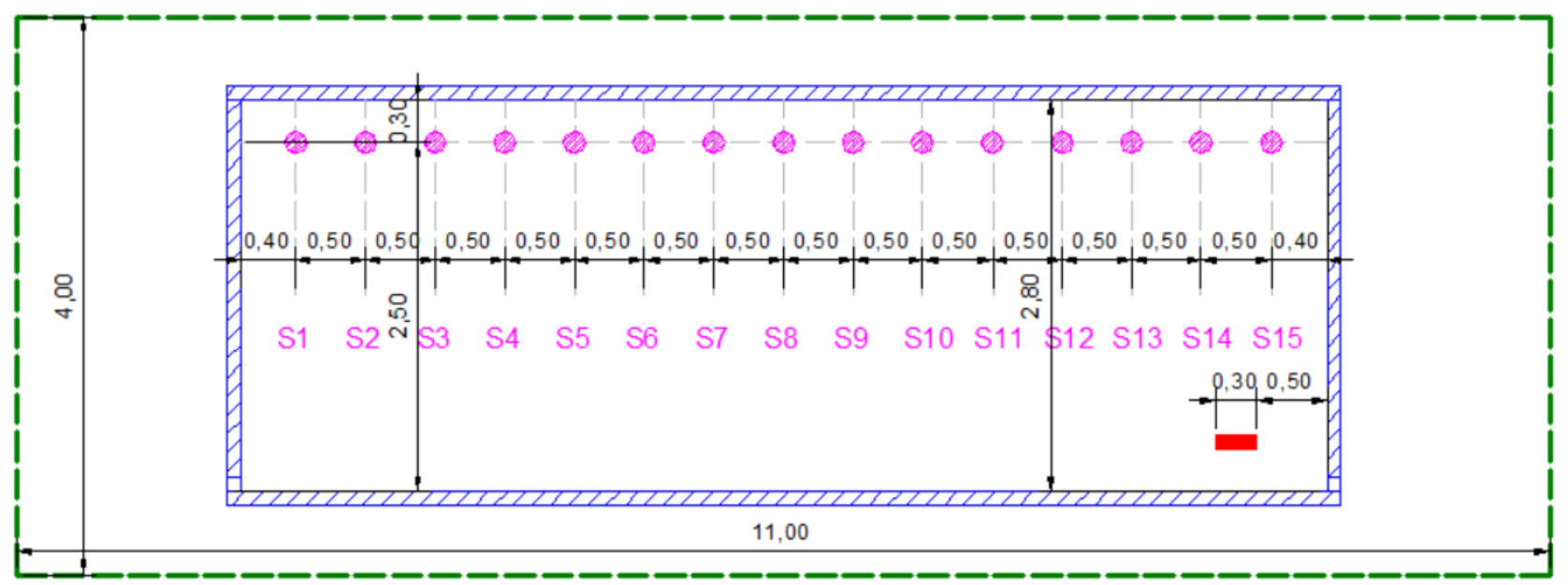

Fig. 6. Position of temperature sensors- section

Another important parameter monitored is the quantity of oxygen(concentration) in the air. An oxygen concentration value greater than $18 \%$ is required for a good evacuation and values below $16 \%$ are dangerous for humans. If the oxygen concentration is below $14 \%$ the burning will cease.
Two sensors for measuring oxygen concentration were placed on $1.50 \mathrm{~m}$ from the floor: O1, O2(fig. 7). Other researchers also used the position $\mathrm{z}=1,50 \mathrm{~m}$ to determine the parameters that characterize the fire [13]. 


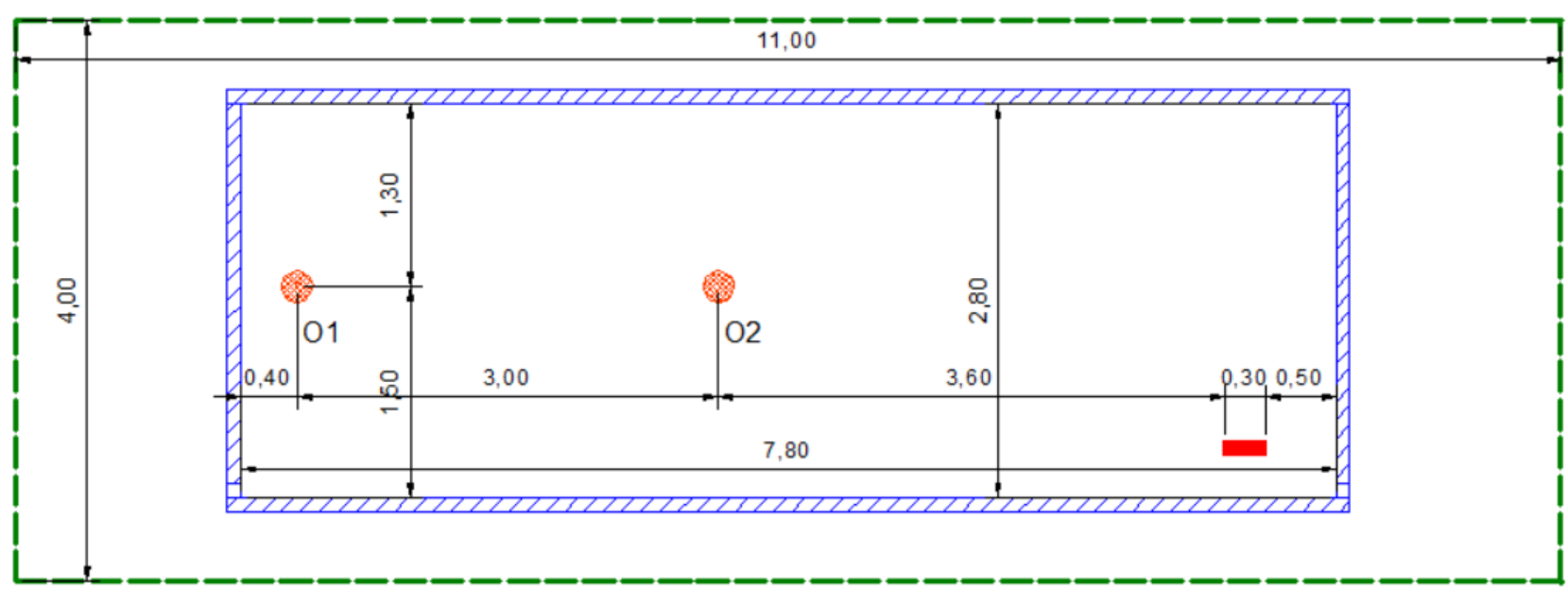

Fig. 7. Position of oxygen sensors- section

\section{Results}

In the current study, during the analysis period, the following output parameters were followed: the visibility, the oxygen concentration and the temperature.

\subsection{Visibility}

An important parameter which was followed is the visibility in the corridor. For each iteration the smoke density is known.

Visibility is the distance that an observer can identify an object relative to the background and obscuration is the amount light intensity is reduced as it passes through smoke[11].

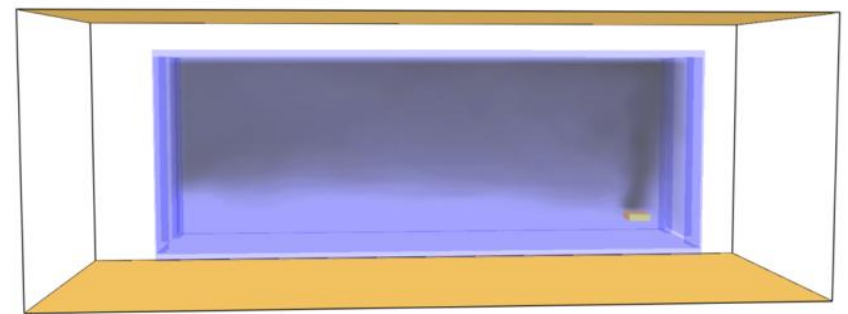

a. $\mathrm{t}=30 \mathrm{~s}$

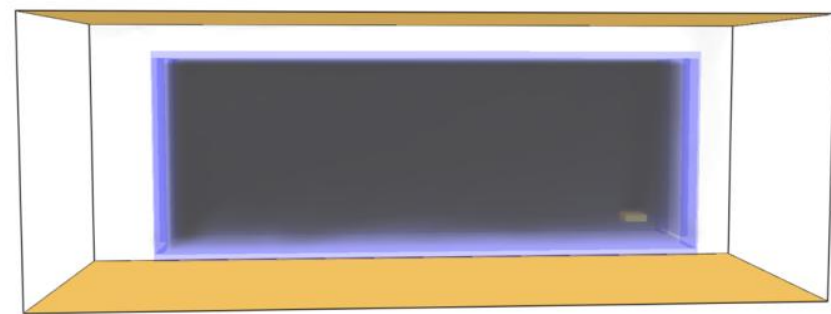

c. $\mathrm{t}=120 \mathrm{~s}$

$$
I=I_{O} e^{-K_{m} \rho_{s} L}
$$

$\mathrm{K}_{\mathrm{m}}$ - mass extinction coefficient $\left[\mathrm{m}^{2} / \mathrm{kg}\right.$ ], $\mathrm{m}]$,

L- the unit of length over wich the light is attenuated

$\rho_{\mathrm{s}}$ - the density of soot $\left[\mathrm{kg} / \mathrm{m}^{3}\right]$,

I- the intensity of monochromatic light [nm],

$\mathrm{I}_{0}$ - the incident intensity [nm].

The visibility was measured in $\mathrm{O}_{1}$ point. It can be noticed that in less than 30 seconds the amount of smoke is significant but the visibility at $1.70 \mathrm{~m}$ of floor is ensured through all the corridor; after 60 seconds the smoke will cover the corridor all its height but the visibility at $1.50 \mathrm{~m}$ of flooring drops below $2.00 \mathrm{~m}$; after 120 seconds the smoke will significantly affect all the surrounding areas but the visibility at $1.50 \mathrm{~m}$ of flooring drops below $1.00 \mathrm{~m}$ (fig. 8 ).

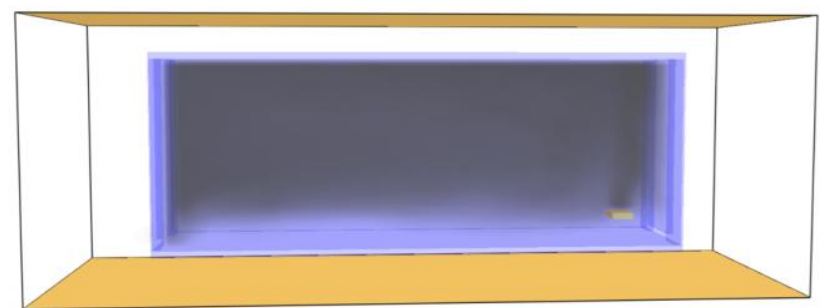

b. $t=60 s$

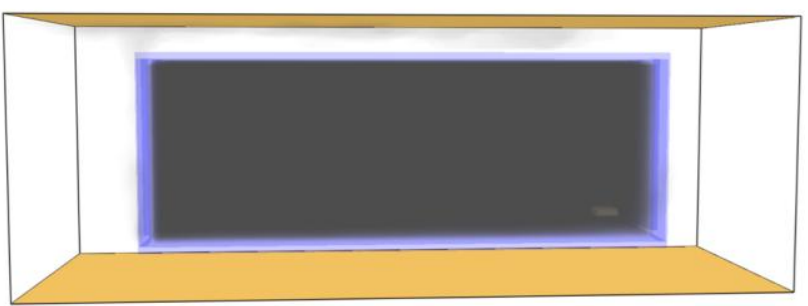

d. $\quad t=240 s$

Fig. 8. Distribution of smoke over time 


\subsection{Oxygen concentration}

The oxygen concentration in the air is an important parameter that has been measured. The ouput values indicate a linear decrease over the analysis period(table 1)

Table 1. Oxygen concentration $\left(\mathrm{S} 1_{\mathrm{O} 2}, \mathrm{~S} 2_{\mathrm{O} 2}\right)$

\begin{tabular}{|c|c|c|}
\hline Time & $\mathbf{O}_{\mathbf{1}}$ & $\mathbf{O}_{\mathbf{2}}$ \\
\hline$[\mathrm{s}]$ & $\%$ & $\%$ \\
\hline 0 & 0,2078 & 0,2078 \\
\hline 30 & 0,2035 & 0,2043 \\
\hline 60 & 0,19990 & 0,2008 \\
\hline 120 & 0,1931 & 0,1940 \\
\hline 240 & 0,1811 & 0,1823 \\
\hline 360 & 0,1694 & 0,1699 \\
\hline
\end{tabular}

Fig. 9.a. and Fig. 9.b. show that in six minutes the quantity of $\mathrm{O}_{2}$, decreased over about $20 \%$ for both sensors. A linear variation is observed, correlated with the fact that HRRPUA has a constant value, so there is a constant consumption rate of the quantity of $\mathrm{O}_{2}$ in space. In fact, a constant value of HRRPUA does not exist in reality, but it is important to notice that the amount of $\mathrm{O}_{2}$ consumed is linearly proportional to HRRPUA, if there is a predominant type of fuel.

A continuous decrease of the oxygen quantity is observed, as expected; at $\mathrm{t}=240$ seconds the quantity decreases from $0.2078(\mathrm{t}=0 \mathrm{~s})$ to 0.1811 . However, leaks from the wall bring fresh air into the corridor from the closer rooms, so that the rate of decline is not so accelerated over the studied period. The quantity of oxygen is inappropriate but it is over the limit to ensure correct evacuation. After six minutes it can be noticed that the values fall below 0.1700 , which can significantly affect evacuation.

The time distribution of oxygen concentration, in the median axis of the corridor, can be seen in fig. 10 .
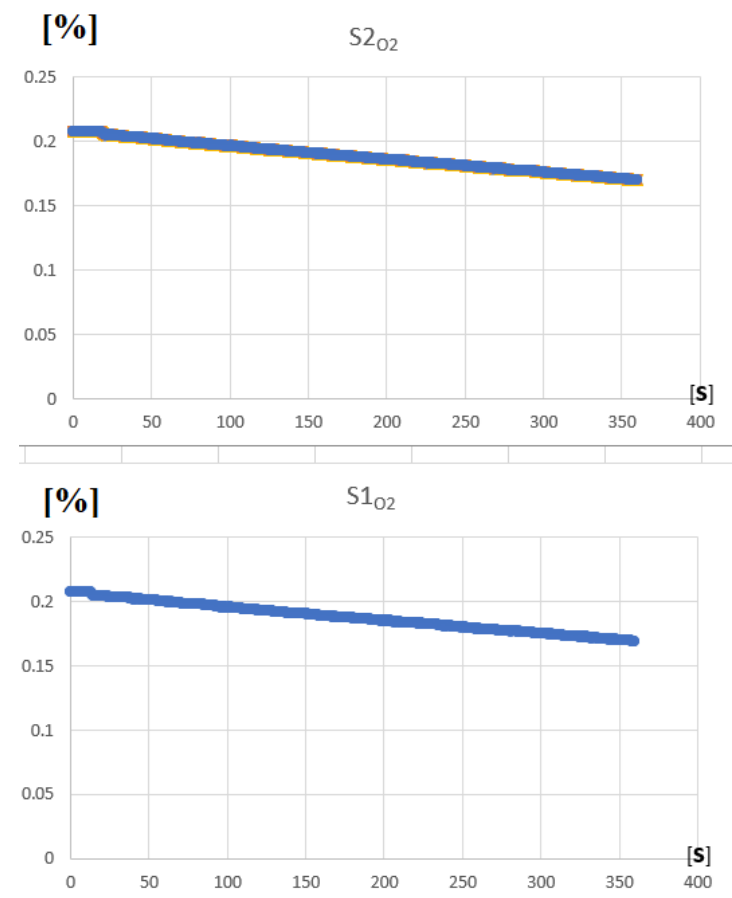

Fig. 9.a. The evolution of $\mathrm{O}_{2}$
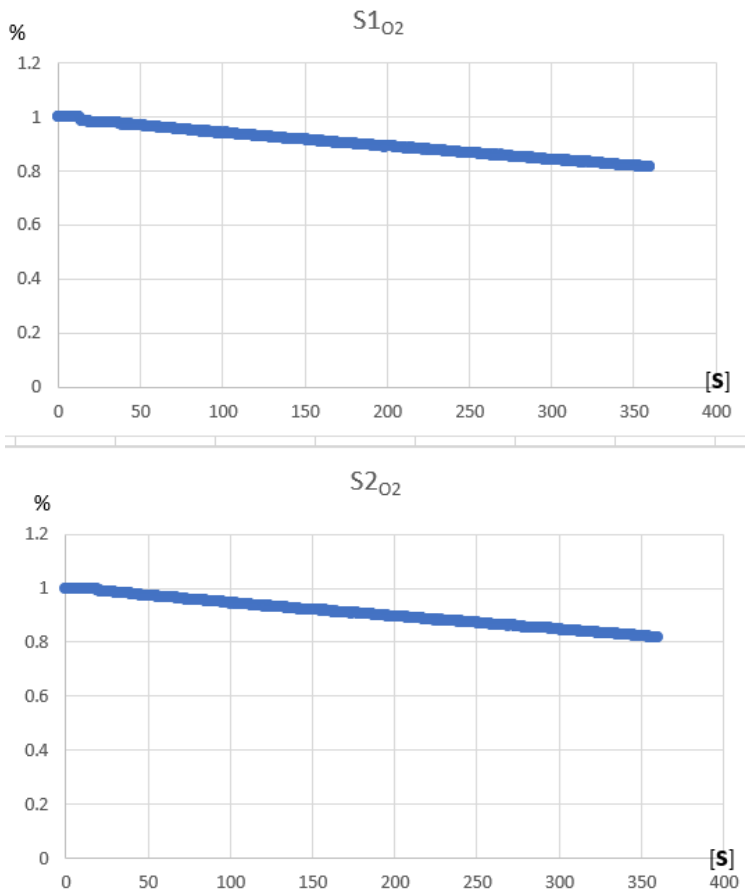

Fig. 9.b. The percentage evolution of $\mathrm{O}_{2}$

Fig. 10 


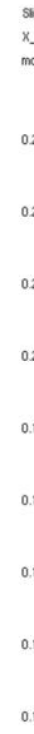

c. $\mathrm{t}=120 \mathrm{~s}$

a. $\mathrm{t}=30 \mathrm{~s}$

0.17

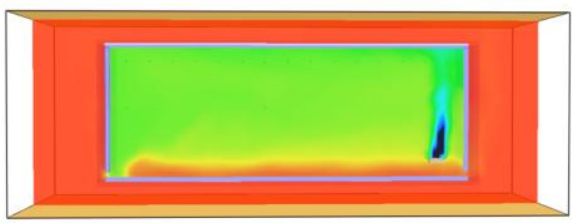

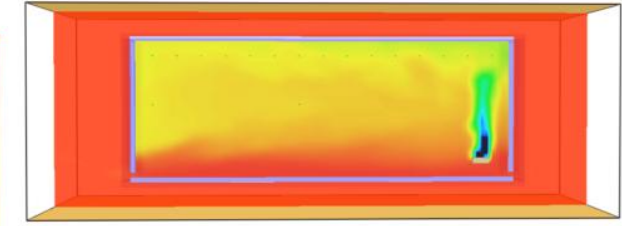

b. $t=60 \mathrm{~s}$

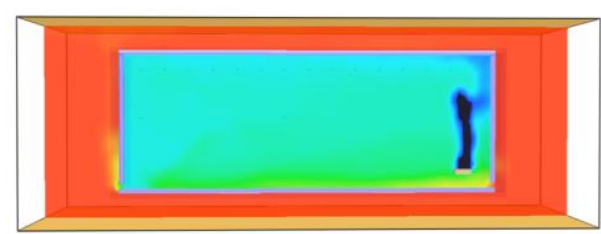

d. $t=240 \mathrm{~s}$

Fig. 10. The Oxygen concentration at $y=0,90 \mathrm{~m}$.

\subsection{Temperature}

The temperature parameter was measured in the 15 sensors located at the ceiling. Table 2 shows the values at different times for three of them.

Table 2. Temperature(S2, S6, S10)

\begin{tabular}{|c|c|c|c|}
\hline Time & S2 & S6 & S10 \\
\hline$[\mathrm{s}]$ & ${ }^{\circ} \mathrm{C}$ & ${ }^{\circ} \mathrm{C}$ & ${ }^{\circ} \mathrm{C}$ \\
\hline 0 & 20,00 & 20,00 & 20,00 \\
\hline 30 & 50,48 & 52,16 & 60,94 \\
\hline 60 & 73,24 & 77,82 & 80,41 \\
\hline 120 & 88,41 & 95,87 & 99,51 \\
\hline 240 & 87,87 & 99,70 & 100,04 \\
\hline 360 & 90,65 & 95,82 & 97,80 \\
\hline
\end{tabular}

Sensors S2, S6, S10 measured the temperature at $\mathrm{z}=$ $2.50 \mathrm{~m}$, in the corridor's median area.

For sensor S10(fig. 6) the temperature value of $57^{\circ} \mathrm{C}$ is reached at time $\mathrm{t}=22 \mathrm{~s}$ and $68^{\circ} \mathrm{C}$ at $\mathrm{t}=34 \mathrm{~s}$. These is the usual sprinkler firing temperatures in civil buildings.

In fig. 11 we can see that there is a stratification of hot air at the top of the corridor. At 60 seconds after the fire starts, the temperature difference between the top and bottom of the corridor is significant (the value is double). The bottom third of corridor is useful for evacuation, while the upper part has temperatures close to those that cause irrecoverable injuries.

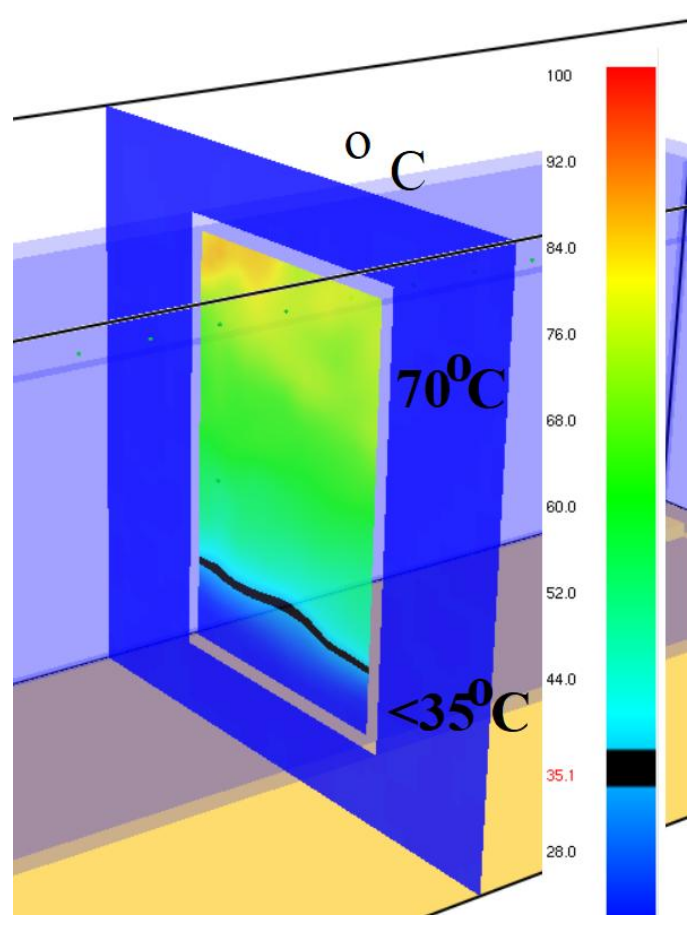

Fig. 11. Temperature distribution at $\mathrm{z}=3,60 \mathrm{~m}$, $\mathrm{t}=60 \mathrm{~s}$

We can see that the situation is almost similar after 120 seconds: the temperature at the bottom of the room is about $60^{\circ} \mathrm{C}$, not perfect, but suitable to ensure evacuation. At the top of the corridor, the temperature exceeds $100^{\circ} \mathrm{C}$, making this area improper for evacuating people. We conclude that it is important for users to know that evacuation using only the inferior third of the corridor or burning space can save lives. 


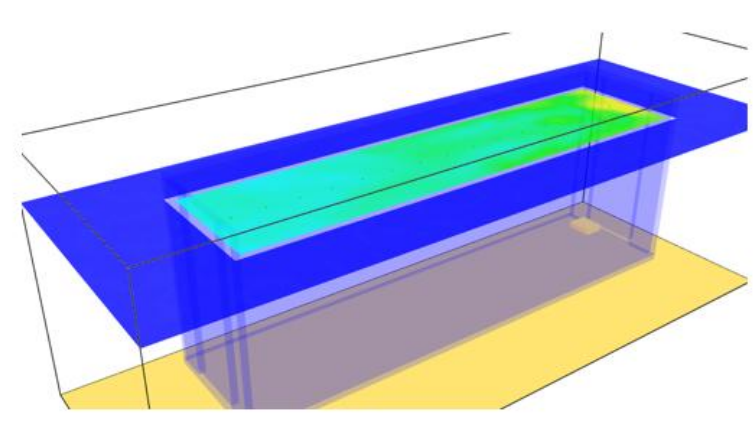

a. $\mathrm{t}=30 \mathrm{~s}$

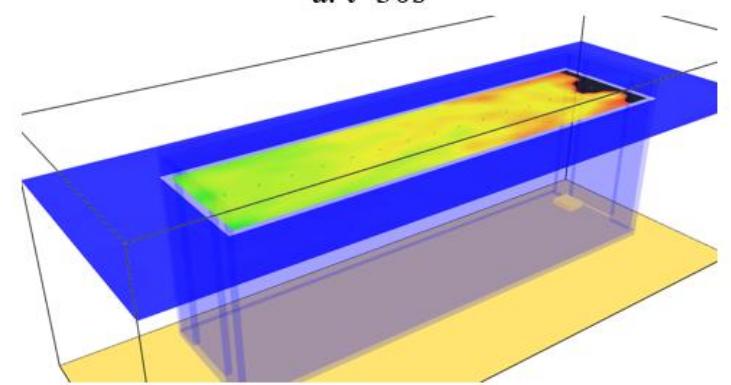

b. $\mathrm{t}=120 \mathrm{~s}$

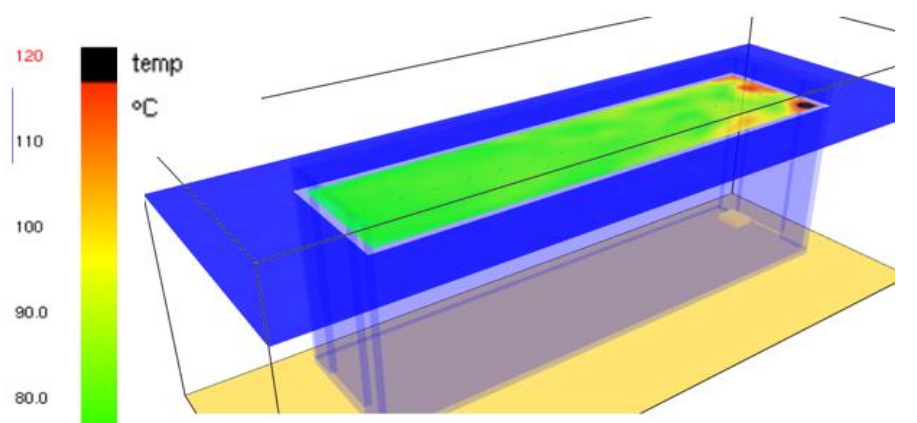

b. $\mathrm{t}=60 \mathrm{~s}$

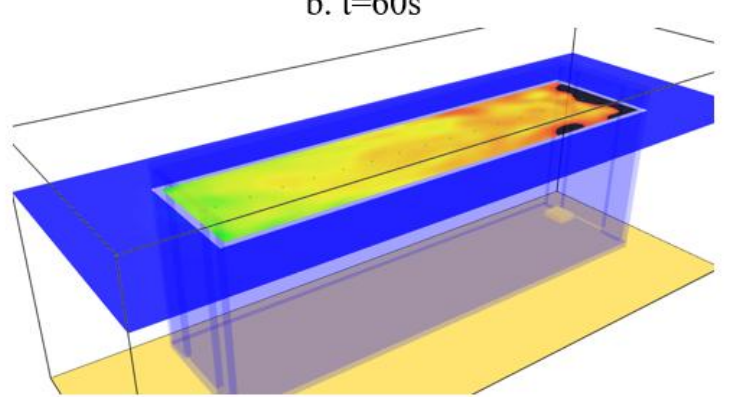

d. $\mathrm{t}=240 \mathrm{~s}$

Fig. 12 Temperature distribution, $z=2,50 \mathrm{~m}$

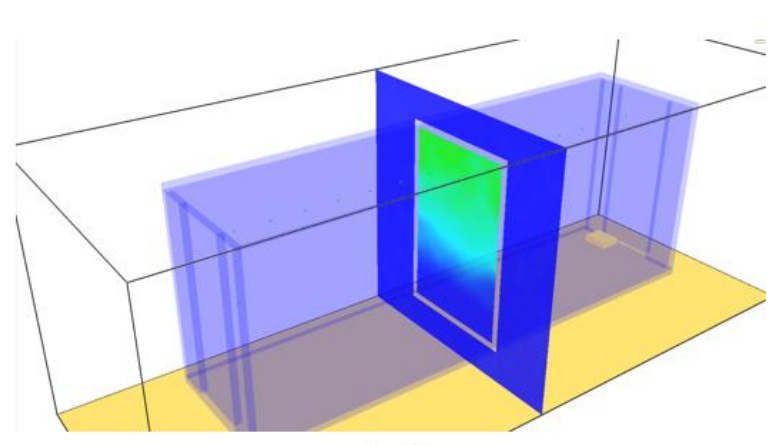

a. $\mathrm{t}=30 \mathrm{~s}$

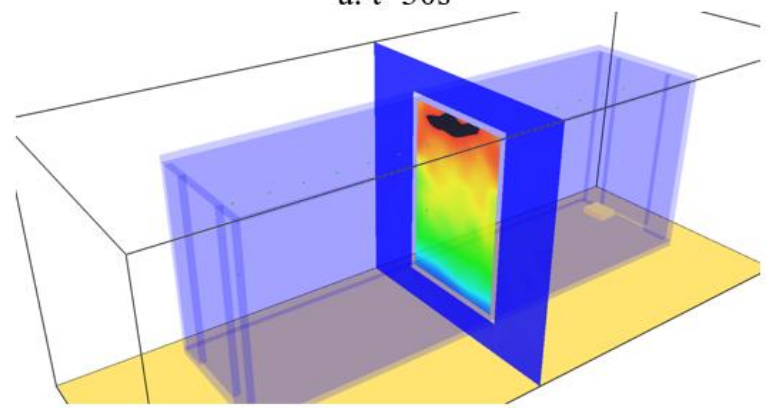

b. $\mathrm{t}=120 \mathrm{~s}$

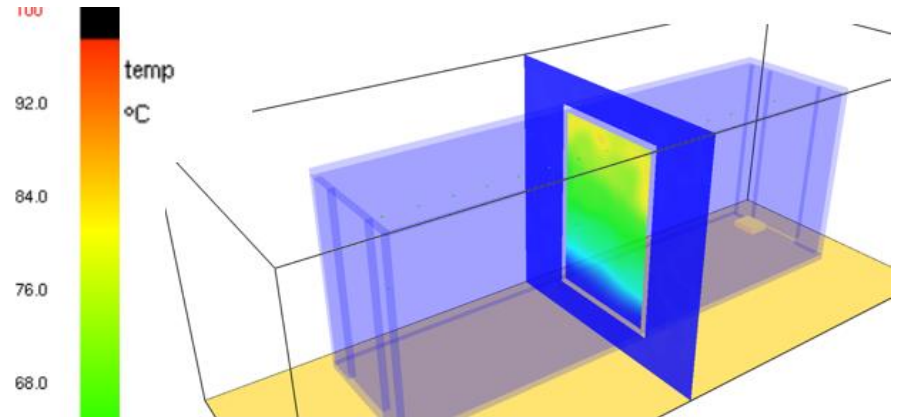

b. $\mathrm{t}=60 \mathrm{~s}$

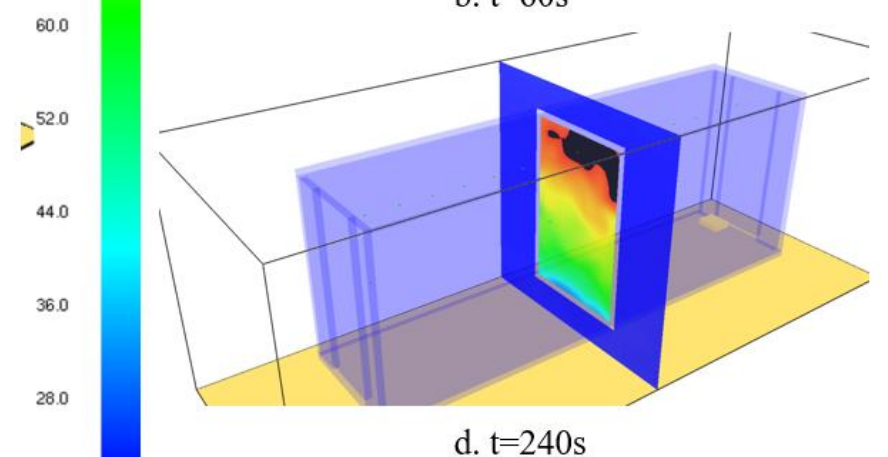

Fig. 13. Temperature distribution, $x=3,90 \mathrm{~m}$ 

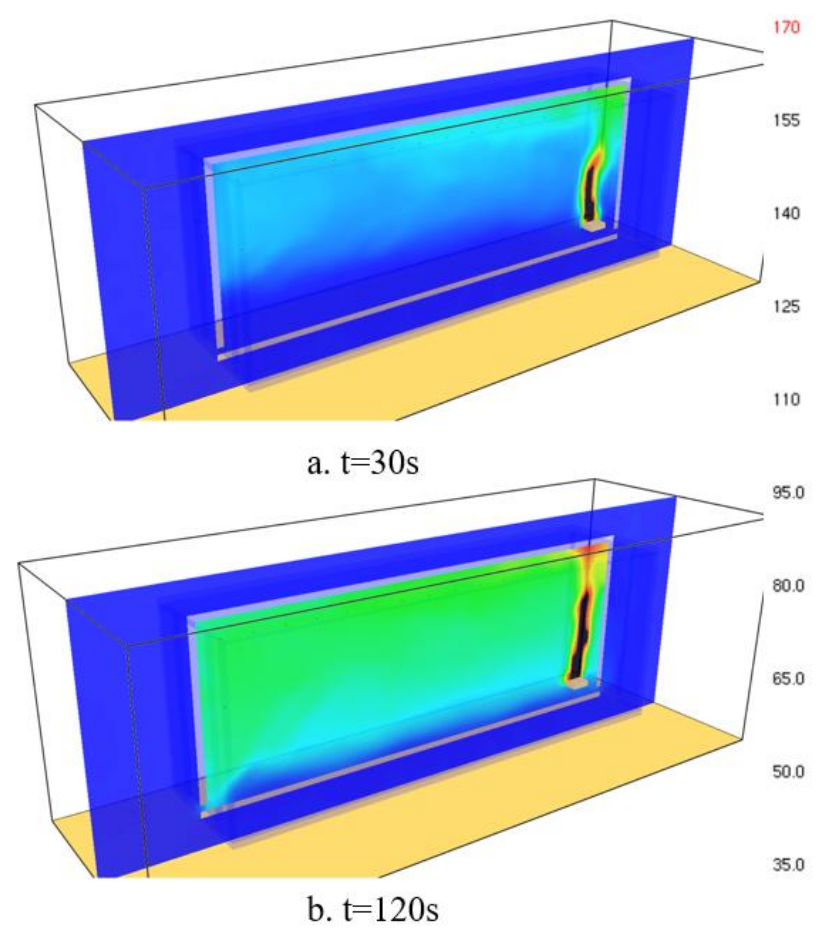
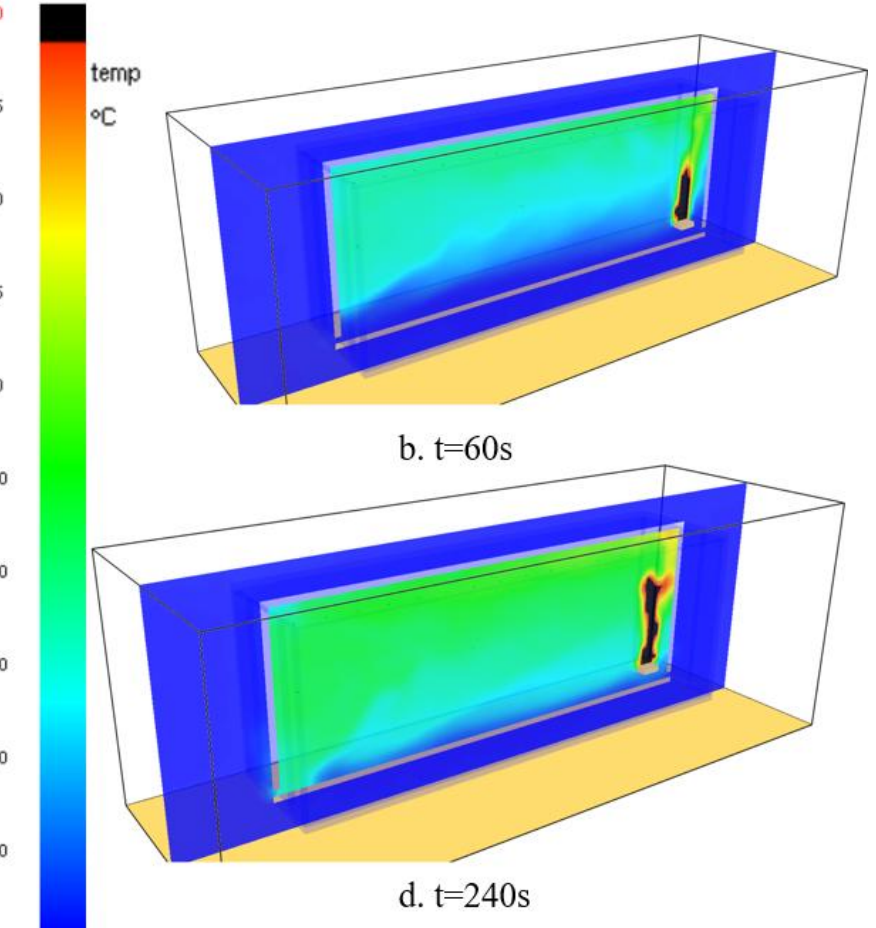

Fig. 14. Temperature distribution, $y=0,90 \mathrm{~m}$

\section{Conclusions}

A modeling of a fire in an nonventilated corridor was performed with F.D.S.. The time evolution of the following parameters have been recorded: visibility, oxygen concentration and indoor temperatures. All the tracking parameters have an important role in determining the escape conditions.

In the first 4 minutes from the start of the fire in the corridor, the changes in the concentration of oxygen is within acceptable limits; after 6 minutes it drops below 0.1700 , which affects the ability of people to react and the efficiency of the evacuation.

The stratification of smoke and hot gas at the top of the corridor was observed; for exemple: at $\mathrm{t}=60 \mathrm{~s}$, temperature $\mathrm{S} 6=77,82^{\mathrm{O}} \mathrm{C}(\mathrm{z}=2,50 \mathrm{~m})$, but at $\mathrm{z}=0,50 \mathrm{~cm}$ the temperature is less than $35^{\circ} \mathrm{C}$.

In the first 60 seconds from the start of the fire in the corridor, smoke is significant; more then $80 \%$ of the space is completely flooded with smoke, and the visibility measured at $1.50 \mathrm{~m}$ is less than $2.00 \mathrm{~m}$.

The temperature values at the same level are sensitively the same. The temperature rises rapidly in space; at $0,30 \mathrm{~m}$ from the ceiling the temperature reach $100^{\circ} \mathrm{C}$ in about 120 seconds.

During 30 seconds the sprinklers will start approximately, all at the same time, because the temperature at $0,30 \mathrm{~m}$ from the ceiling reach $68^{\mathrm{O}} \mathrm{C}$.

Studying these aspects we can draw the conclusion that once a fire has started in the unventilated corridor, during less than a minute the corridor becomes inappropriate for evacuation. Therefore, an early alert of the users about the existence of a fire is required and it is necessary to take measures to prevent the fire to expands inside the corridor. The model shows that every second counts.

The short-term during which smoke floods the space shows that it is necessary for the corridors to be equipped with devices for the natural-organized smoke evacuation or mechanical smoke evacuation, preferably with manual and automatic start.

Another important conclusion is that the provision of sprinklers in such spaces produces positive effects because their action leads to limiting and even extinguishing the fire. The difference between the $57^{\circ} \mathrm{C}$ sprinklers and $68^{\circ} \mathrm{C}$ sprinklers is not so important because the trigger difference is only a few seconds. When ventilation is not possible for various reasons, the provision of sprinklers in the corridor may be an alternative protective measure, cumulative with passive fire protection measures(walls, floors, doors with fire resistance characteristics). It is known that the use of sprinklers together with mechanical ventilation systems causes a delay in triggering of the first category[14].

\section{Acknowledgement}

Thanks to $d r$. Kevin McGrattan(from NIST) and $d r$. Lukas Arnold(from Julich Supercomputing Centre), who have organized Summer School of Fire Dynamics Modeling 2017 and helped us to understand the phenomenon behind the F.D.S. algorithm, the simplifications and limitations of the software. 


\section{References}

[1] Legea 307:2006, privind Apărarea împotriva incendiilor;

[2] P118-99 Normativ de siguranță la foc a construcțiilor

[3] R. Baldwin, P.H. Thomas, Passive and Active Fire Protection- The optimum Combination, Department of Environment and Fire Offices' Committee, 1974

[4] P118/2: 2013 Normativ privind securitatea la incendiu a construcțiilor. Partea a II-a- Instalații de stingere;

[5] NFPA 13: 2017, Standard for the Installation of Sprinkler Systems;

[6] SR EN 1991-1-2: 2013 Eurocod 1: Acțiuni asupra structurilor. Partea 1-2: Acțiuni generale. Acțiuni asupra structurilor supuse incendiului;

[7] Pietreanu Costel, Strugariu Robert, Petcana Cătălin, Inspectoratul General pentru Situaţii de Urgenţă

[8] Fire Dynamics Simulator. Technical Reference Guide. Volume 1: Mathematical Model, 2017

[9] K. McGrattan, S. Hostikka, R. McDermott, J. Floyd, C. Weinschenk, K. Overholt, Fire Dynamics Simulator. User's Guide, 2017

[10] G.W. Mulholland, C. Croarkin, Specific Extinction Coefficient of Flame Generated Smoke, Fire and Materials, 2000

[11] SR EN 12845:2016 Instalații fixe de luptă împotriva incendiului. Sisteme automate de stingere tip sprinkler. Dimensionare, instalare, întreținere;

[12] X.G. Zhang, Y.C. Guo, C.K. Chan, W.Y. Lin, Numerical simulation on fire spread and smoke movement in an underground car park, Elsevier, 2006

[13] Qing Li, Si-cheng Li, Zi-heng Wang, Research on smoke exhaustic effect at different installation height of mechanical exhaustic port in ring corridor of high-rise building, Elsevier, 2015

[14] P.A.(Tony) Enright, Case Studies in Fire Safety, Impact of fan ventilation systems on sprinkler activation, Elsevier, 2014

[15] J. Outinen, J. Samec, Z. Sokol, Research on fire protection methods and case study "Futurum", Elsevier, 2012 